\title{
Some Aspects of Red Special Wines
}

\author{
Temur Gvinianidze ${ }^{1 *}$ and Teona Gvinianidze ${ }^{2}$ \\ ${ }^{1}$ Professor, Department of Engineering Science, Kutaisi, Georgia \\ ${ }^{2}$ Academic Doctor, Kutaisi, Georgia
}

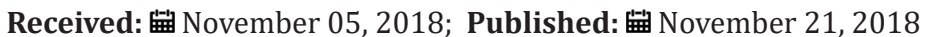

*Corresponding author: Temur Gvinianidze, Professor, Department of Engineering Science, Kutaisi, Georgia

\begin{abstract}
Due to increasing environmental radionuclide background, the scientists and specialists constantly face the problem of developing technologies for producing plant-based, therapeutic-purpose foods and food supplements enriched with biologically active substances, which are characterized by high immunomodulating, radioprotective and antioxidant activity. From such therapeutic-purpose foods and food supplements, of particular importance are the beverages because their improved composition, sensory and liquid consistency provide high availability and increased therapeutic capacity.
\end{abstract}

Keywords: Radionuclide; Antioxidant Activity; Grapes; Food; Special Wine

\section{Introduction}

Natural and special wines form the great part of the export potential of Georgia. The fact that according to figures on exports of wine and alcoholic beverages only for the first nine months of 2017, Georgia exported 52.7 million bottles (0,75 l) of wine. According to the National Wine Agency, wine exports have grown up on $63 \%$ in comparison with corresponding period last year $[1,2]$. It is also noteworthy that since the 80 s of the last centuries, poor-quality and expensive sprays and brought to our country have caused significant damage to the indigenous and alien grape varieties. Georgian farmers were forced to switch partly to growing of nontreated and hybrid grape varieties, because they do not require expensive and imported from outside sprays, and besides, hybrids and clones are easy to grow, and different types of fungi and other diseases are no big deal for them. Today, wineries cannot apply even industrial varieties of colored grapes such as Aladasturi, Dzelshavi, Mgaloblishvili and Black Pinoa [3,4].

In view of the foregoing, it reasonable and relevant to develop the innovative technologies for producing natural and special wines from common to western Georgia Therefore reasonable and relevant to western Georgia-known less marketable local raw materials of colored grape industrial varieties and nontreated grape clones enriched with from biologically active substance enriched with innovative technology of special wines, which are characterized by high sensor, radioprotective and antioxidant activity therapeutic properties for preventing food-borne diseases [5-7]. The goal of the work is to develop special wine technology enriched with biologically active substances from the grape raw materials of grape varieties cultivated in the Imereti Viticulture and Winemaking Area, which is characterized by improved sensory indicators and increased therapeutic and preventive capacity. In addition, in this special wine technology, for the first time in Georgia, there will be used raw materials of the nontreated colored Zeibeli grape variety cultivated in the Baghdati Viticulture and Winemaking micro-zone, rosehip and grape-seed alcohol-wine extracts and small quantity of white honey for the purpose of increasing the flowers tonality.

Objectives and Methods

\section{Object of Study}

Raw materials of "Otskhanuri Sapere" grape variety from the Imereti Viticulture-Winemaking subzone, particularly from the Zestafoni district's village of Sviri and the Bagdati district's village of Obcha; raw materials of "Aladasturi" grape variety from the Middle and Lower Imereti Viticulture-Winemaking subzone, particularly from the Bagdati district's village of Rokhi and the Vani district's villages of Pereti and Kumuri, from the Patele Area's vineyards; raw materials of "Zeibeli 5455" ("Zeimberi") grape variety from the Lipnari vineyards; vacuum-must; grape-seed extract; wildgrowing dog-rose from the Zekari and Sairme valleys and extracts 
and concentrates obtained from their skins and fleshes; lime-tree flower honey from the Zekari and Sairme valleys; rectified ethyl alcohol [8].

\section{Research Methods}

When determining the physical-chemical indicators of grape raw materials, wine materials and finished special wine, we used the standard, universally accepted and modified organoleptic and physical-chemical methods, including chromato-massspectrometry, high-performance liquid and gas chromatography, spectrophotometry and fluorometry.

\section{Results and Analysis}

To implement this goal, the following objectives should be attained [9-14]:

a. To study the mechanical composition of selected raw materials;

b. To provide uvological evaluation of raw materials;

c. To study the chemical composition and sensory characteristics of raw materials;

i). To justify theoretically and experimentally the optimal composition of grapes raw material required for special wine

ii). To develop rational technology of colored grape raw materials processing, alcoholic fermentation and ageing;

iii). To study the influence of thermal conditioning regimes of the seeds and skins on the extraction of phenolic and dye compounds; iv). To develop the optimal technological regimes and approaches for the production of ingredients required for special wine: semi-fermented wine, condensed grape vacuum-must, and grape-seed and dog-rose extracts;

v). To provide quantitative and qualitative evaluation of biologically active substances of special wine;

vi). To develop technological schemes for producing ingredients of special wine;

vii). To develop technological schemes for special wine production;

viii). To assess sensory characteristics and antioxidant activity of special wine.

ix). At the initial stage we studied and evaluated the mechanical, physical, chemical and sensory characteristics of the selected grape raw materials.

The grapes are the main raw material for wine production, and we have identified the mechanical composition of the bunch in compliance with the requirements suggested by Prostoserdov. (Table 1) We have carried out studies and evaluation of the chemical composition and variety flavor of selected grape raw materials (Table 2). Studies show that the value of sugar-acid ratio affects numerous characteristics of wine, in particular the higher is this ratio, the better is the quality of special wine. Along with the selection of high-quality raw materials in the production of red special wines, the fermenting and fermentation processes have the main function in the formation of a sensory bunch $[15,16]$.

Table 1: The uvological characteristics of grape varieties from Imereti.

\begin{tabular}{|c|c|c|c|c|}
\hline \multirow{4}{*}{} & $\begin{array}{c}\text { Separate Parts of A Bunch and } \\
\text { Their Compositions }\end{array}$ & \multicolumn{2}{|c|}{ Grape varieties } \\
\cline { 2 - 5 } & Stalk & Otskhanuri & Zeibeli & 4,21 \\
\cline { 2 - 5 } A bunch of grapes, \% & Grapelet skins & 3,67 & 3,27 & 9,87 \\
\cline { 2 - 5 } & Grape seed & 8,63 & 9,55 & 3,97 \\
\cline { 2 - 5 } & Juice and flesh & 3,23 & 83,67 & 14,58 \\
\cline { 2 - 5 } & Skeleton (stalk and skins) & 82,98 & 12,65 & 14,08 \\
\cline { 2 - 5 } & Solid waste & 12,29 & 19,22 & 93,05 \\
\cline { 2 - 5 } & Grapelet-content & 15,53 & 109,0 & 93.17 \\
\cline { 2 - 5 } & Structural indicator & 94,6 & 4,37 & 4,52 \\
\hline
\end{tabular}

Table 2: Physical-chemical characteristics of the selected grape raw materials.

\begin{tabular}{|c|c|c|c|c|c|}
\hline Grape variety & $\begin{array}{c}\text { The yield of Must } \\
\text { (juice), \% }\end{array}$ & $\begin{array}{c}\text { Mass Content of } \\
\text { Dry Substances, \% }\end{array}$ & $\begin{array}{c}\text { Mass } \\
\text { Concentration of } \\
\text { Sugars g/100 } \mathbf{c m}^{\mathbf{3}}\end{array}$ & $\begin{array}{c}\text { Mass Concen- } \\
\text { tration of Titrating, } \\
\text { Acids g/100 } \mathbf{~ c m}^{\mathbf{3}}\end{array}$ & $\begin{array}{c}\text { Active Acidity, pH } \\
\text { Sugar-acid Ratio }\end{array}$ \\
\hline Otskhanuri & 72,5 & 22,9 & 22,3 & 0,74 & 3,4 \\
\hline Zeibeli & 70,4 & 23,9 & 23,7 & 34,14 & 3,65 \\
\hline Aladasturi & 71,1 & 22,7 & 22,2 & 34,68 \\
\hline
\end{tabular}




\section{The List of the Proposed Innovations is as Follows:}

I. Adding of pectolytic (with activity 2000-2200 unit/g) enzyme (Rapides CR) to the seeds and skins during the process of pressing in a grape stalk separator, increases the yield of the must by $5-7 \%$ and the content of biologically active substances for $1-2 \mathrm{ml} / 100 \mathrm{~kg}$.

II. Adding of potassium metabisulfite within $54-63 \mathrm{mg} / \mathrm{dm}^{3}$ significantly increases extraction of anthocyanins, increases to $1.2-4.3 \mathrm{~g} / \mathrm{dm}^{3}$ the reduced extract and the content of dyes, contributes to purification, the growth in terpenic compounds by $2,1-2,7 \%$, and the growth in a stable fraction of a phenolic complex (within 20-25\%) in wine.

III. We added 1-2\% of Aspergillus fungus of the dry active yeast in a grape stalk separator (C-R-9001 or C-RB-9001- fungus works at the temperature of $12-28^{\circ} \mathrm{C}, \mathrm{pH}=3.0-5.4$ and increases alcohol content up to $24 \%$, and significantly increases the content of terpens and esters in wine).

IV. Adding of the condensed concentrate with the content of dry substances up to 54-63\% through the dog-rose lyophilic drying to the seeds and skins within $50-75 \mathrm{mg} / \mathrm{dm} 3$, in the presence of or cadifite $\left(40-70 \mathrm{mg} / \mathrm{dm}^{3}\right)$ either $\mathrm{SO}_{2}(90 \pm 10 \mathrm{mg} /$ $\mathrm{dm}^{3}$ ) increases by 1.5-1.8 the development of variety flavor in a special wine.

V. During the fermentation of the seeds and skins, we raised the sugar content up to $27 \%$ by adding the vacuum-must and honey, due to which terpenic compounds were increased by $0.7-1.2 \%$, and esters by $24-27 \%$.

VI. We have established that after tye 6-day extractionfermentation at a temperature of $27^{\circ} \mathrm{C}$, the seeds and skins are subject to heat treatment at a temperature of $54^{\circ} \mathrm{C}$, and hot pressing, which significantly increases separation of phenolic and dye compounds.

VII. Adding of the grape-seed and dog-rose concentrates and heat-treated grape-seed ( $5 \mathrm{~g} / \mathrm{dal}$ ) and oak shavings ( $5 \mathrm{~g} / \mathrm{dal})$ significantly improves the rancio tones and sensory bunch.

VIII.In 16-18 months, adding of dry dog-rose pulp and peel (20 g/ dal) increases the flavor-forming complexes.

IX. Adding of the grape-seed and dog-rose concentrates and heat-treated grape-seed during the ageing process, under conditions of periodic pasteurization and stirring within 2-3 months, increases the total amount of phenols by $0.3-0.4 \mathrm{~g} /$ $\mathrm{dm}^{3}$, and improves the rancio tones and sensory bunch.

X. Prohibition of using gelatin and bentonite clays, because for processing wine materials, bentonite clays reduced the anthocyanins by $27-36 \%$ on $2-3 \mathrm{~kg} / \mathrm{t}$, while the use of gelatin reduced the compounds of phenolic compounds by $6-9 \%$ on $2-3 \mathrm{~g} / \mathrm{t}$.
XI. Creating a new technology by using new varieties and honey flower tones.

XII. We have studied the impact of the temperature of the fermentation of the seeds and skins on the extraction process anthocyanins from the skins in the fermenting mass. Studies were carried out at four temperature intervals $34-36^{\circ} \mathrm{C}, 27$ $30^{\circ} \mathrm{C}, 21-25^{\circ} \mathrm{C}$ and $16-18^{\circ} \mathrm{C}$.

Table 3: Physical and chemical characteistics of pomace fermentation.

\begin{tabular}{|c|c|c|}
\hline $\begin{array}{c}\text { Fermentation } \\
\text { Temperature }\end{array}$ & $\begin{array}{c}\text { Time of the } \\
\text { Maximum } \\
\text { Concentration of } \\
\text { Anthocyanins, hr. }\end{array}$ & $\begin{array}{c}\text { The Density of the } \\
\text { Fermented mass during the } \\
\text { Maximum Concentration of } \\
\text { Anthocyanins }\end{array}$ \\
\hline 16-180C & $36-42$ & $1,033-1,035$ \\
\hline 21-250C & $18-24$ & $1,042-1,045$ \\
\hline 27-300C & $12-16$ & $1,051-1,055$ \\
\hline 34-360C & $6-10$ & $1,060-1,062$ \\
\hline
\end{tabular}

Table 4: Special wine characteristics after the 18-month ageing.

\begin{tabular}{|c|c|}
\hline Characteristic & Value \\
\hline Ethyl alcohol volume content, \% & 14,5 \\
\hline Sugars mass concentration, $\mathrm{g} / \mathrm{dm}^{3}$ & $45-48$ \\
\hline Titrating acidity mass concentration, $\mathrm{g} / \mathrm{dm}^{3}$ & $8,7-8,9$ \\
\hline Reduced extract mass concentration, $\mathrm{g} / \mathrm{dm}^{3}$ & 32,87 \\
\hline $\begin{array}{l}\text { Volatile acids mass concentration equivalent to } \\
\text { vinegar acid, } \mathrm{g} / \mathrm{dm}^{3}\end{array}$ & 0,48 \\
\hline Dye substances, mg. 1 & 749,89 \\
\hline Phenolic compounds, mass concentration, $\mathrm{g} / \mathrm{dm}^{3}$ & 3420 \\
\hline \multicolumn{2}{|l|}{ Including: } \\
\hline Monomeric forms & 2270 \\
\hline Polymeric forms & 1150 \\
\hline Tasting evaluation, scores & 9,3 \\
\hline
\end{tabular}

Table 3 shows the main fermentation temperature, the duration of maximum extraction of anthocyanins and the density of the fermented mass. Table 4 contains the physical, chemical and sensory characteristics of the special wine after the 18-month aging. In all five samples, the content of raw materials of Zeibeli grape variety varied between $10-20 \%$, while the amount of raw materials Aladasturi and Otskhanuri Sapere grape varieties - between 2050\%. Aladasturi and Otskhanuri Sapere grape varieties were blended in the proportion 36:48:16 (percentage ratio). As shown from the table, the wine produced has a high sensitivity rate $(9,7$ cents), which is the result of the composite effects of the selected raw materials of the selected raw materials, the use of ingredients and the technological processes of individual technologies.

\section{Conclusion}

A. It has been experimentally determined that the grape picking should be done when the concentration of the sugar content in the grapes is not less than $23-24 \mathrm{~g} / 100 \mathrm{~cm}^{3}$ and titrated acidity is $6-8 \mathrm{~g} / \mathrm{dm}^{3}$. And pressing of grapes in a rolling grape 
stalk separator enriches the seeds and skins with the phenolic complexes of stalk.

B. It has been established that colored grape raw materials blended with an optimal ratio of "Aladasturi", "Otskhanuri Sapere" and "Zeibeli 5455" grape varieties is promising for the production of high-quality special red wines with a distinctive variety flavor, and rich technological reserves of phenolic (3765-4314 mg/kg) and dye (976-1432 mg/kg) compounds.

C. The optimal version of blending for producing a special dessert wine with the best sensory bunch has been determined experimentally:(“Otttsanuri Sapere"): ("Aladasturi”): ("Ziebeli $5455 ")=(27-36 \%):(42-54 \%):(16-18 \%)$.

D. It has been investigated that in the process of pressing in a grape stalk separator, in the composition with the enzyme preparation Rapidase CR the kernel gap in the 1-2 mL / $100 \mathrm{~kg}$ of enzyme preparation in potassium metabisulphite with 54$63 \mathrm{mg} / \mathrm{dm}^{3}$ and special (dry active yeast) Aspergillus fungus 1- 2\% Composition (CR-9001 or C-RB-9001-fungus works at temperature of $12-28^{\circ} \mathrm{C}, \mathrm{pH}=3,0-5,4$ and stands alcohol up to $24 \%$ ), increases the the yield of must, sensory characteristics, the content of extractive (increases the reduced extract up to $1,2-4,3 \mathrm{~g} / \mathrm{dm}^{3}$ ) and dye substances in wine and contributes to its rapid purification.

E. It has been established that sulphiting of the seeds and skins with potassium metabisulphite with $54-63 \mathrm{mg} / \mathrm{dm} 3$, contributes to the emergence of the variety flavor (increase of terpenic compounds by $2,1-2,7 \%$ ) and the increase in phenolic complex (within 20-25 in wine).

F. There has been determined the relationship between the creation of the flavor-forming complexes and the sugar mass concentration in grapes raw materials, in particular the content of terpenic compounds is increasing by $0,7-1,2 \%$, and the content of esters-by $16-27 \%$ when the sugar content in grapes raw materials is $22-27 \mathrm{~g} / 100 \mathrm{~cm} 3$, then when sugar content in the grapes is less than $18.6 \%$.

G. It has been studied that through the dog-rose lyophilic drying until 54-63\%, adding of the condensed concentrate to the seeds and skins within $50-75 \mathrm{mg} / \mathrm{dm}^{3}$, in the presence of or cadifite $\left(40-70 \mathrm{mg} / \mathrm{dm}^{3}\right)$ either $\mathrm{SO}_{2}\left(90 \pm 10 \mathrm{mg} / \mathrm{dm}^{3}\right)$ increases by 1.5-1.8 the development of variety flavor in a special wine

H. It has been experimentally determined that during the aging process of wine material, adding of:

i). dehydrated dog-rose pulp and peel at $20 \mathrm{~g} / \mathrm{dal}$,

ii). thermally-treated oak crumb at $5 \mathrm{~g} / \mathrm{dal}$,

iii). thermally-treated grape-seed at $5 \mathrm{~g} / \mathrm{dal}$
I. Under conditions of periodic pasteurization and stirring within 2-3 months, increases the total number of phenols by 0.3-0.4 g/ $/ \mathrm{dm}^{3}$, improves the rancio tones and sensory bunch.

J. It has been established that after completion of ripening (1618 months), adding of dog-rose condensed extract to wine material within $50-70 \mathrm{mg} / \mathrm{dm}^{3}$, slows down the phenolicquinone transformations and increases the flavor-forming complexes.

\section{References}

1. TNGvinianidze, PMChikovani, TTGvinianidze, RHJabnidze, VAMindeli (2017) Colored grape polyphenol concentrate. Scientific Journal "Annals of Agrarian Science" Tbilisi, Georgia 15[4]: 472-475.

2. http://www.prostoflora.ru/xim.vino/22.html.25.10.2018

3. TN Gvinianidze, PM Chikovani, VA Mindeli, RH Djabnidze (2017) Colored Grapes Byproducts as the Source for Bio-active Products. Scientific Journal “Juvenis scientia" Sank-Peterburg, Russia, 8: 8-10.

4. Gvinianidze TN, Arzumanian AN, Mamrikishvili LG, Gvinianidze TT (2015) Storage of Wine-Making Secondary Resources as the Richest Source of Biologically Active Substances-PROCEEDINGS of National Polytechnic University of Armenia. Yerevan, Armenia, p.40-47.

5. M Gabidzashvili (2018) Developing technologies and quality control methods of Georgian grape seed bioplavonoid liquid extracts. The thesis presented for the academic degree of the doctor, pp.121.

6. Gvinianidze TN (2017) The grape skins and seed polyphenolic extracts. Scientific Journal "Bulletin of Science and Practice" Nizhnevartovsk, Russia 9(22): 81-91.

7. EN Kishkovsky, IM Skurikhin (1976) Chemistry of Wine, food Industry. "Food industry" Moscow, Russia.

8. Gvinianidze T (2018) Micro powder and liquid extracts from rose hips (Fructus Rosae). Bulletin of Science and Practice 4(9): 121-127.

9. TN Gvinianidze, TT Gvinianidze, PM Chikovani, VA Mindeli, RH Djabnidze (2017) Colored Grapes Byproducts as the Source for Bio-active Products. Scientific Journal “Juvenis scientia” Sank-Peterburg, Russia 8: 8-10.

10. Vernikovskaya NA (2011) Chromatographic determination of phenolic compounds and flavonoids in medicinal plants, pp.120.

11. M Vanidze, A Kalandia (2010) New \& Used HPLC of the flavonols of Research: THE VEGETATIVE: local in the Raw Materials is a Works of international scientific-practical conference " INNOVATIVE TECHNOLOGIES AND CONTEMPORARY MATERIALS» Kutaisi, pp. 394395.

12. M Vanidze, I Japaridze, A Kalandia, E Kamadadze (2010) HPLC Research of Anthocyans the Local Vegetative Raw Materials. Works of international scientific-practical conference «INNOVATIVE TECHNOLOGIES AND CONTEMPORARY MATERIALS» Kutaisi, 395-396.

13. Okawa M, Kinjo J, Nohara T, Ono M (2001) DPPH (1,1-Diphenyl-2Pierylhydrazyl) Radical Scavenging activity of Vlavonoids Obtained from Some Medical Plants. Biological and Pharmaceutical Bulletin, 24 (10 ): 1202-1205.

14. Starinskaia A (2012) Determination of vitamin C fruit juices, p.12.

15. Ranjitha CY, Pryanka S, Deepika R (2014) Antimikrobial activity of grape seed extract. 3(8): 1483-1488.

16. Mindeli Varlam, Chikovani Papuna, Gvinianidze Temuri (2017) Study of the Patterns of Extracting Biologically Active Compounds from GrapeStone of Otskhanuri Sapere Variety. Bulletin of Akaki Tsereteli State University. Kutaisi, Georgia 1(9):19-28. 
(c) (i) This work is licensed under Creative

To Submit Your Article Click Here: Submit Article

DOI: 10.32474/OAJESS.2018.01.000116

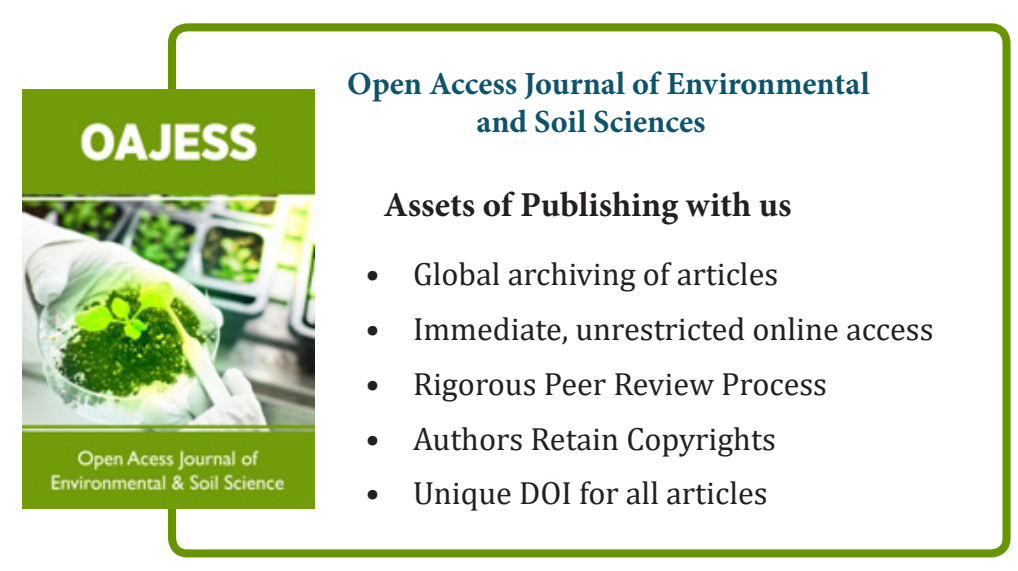

